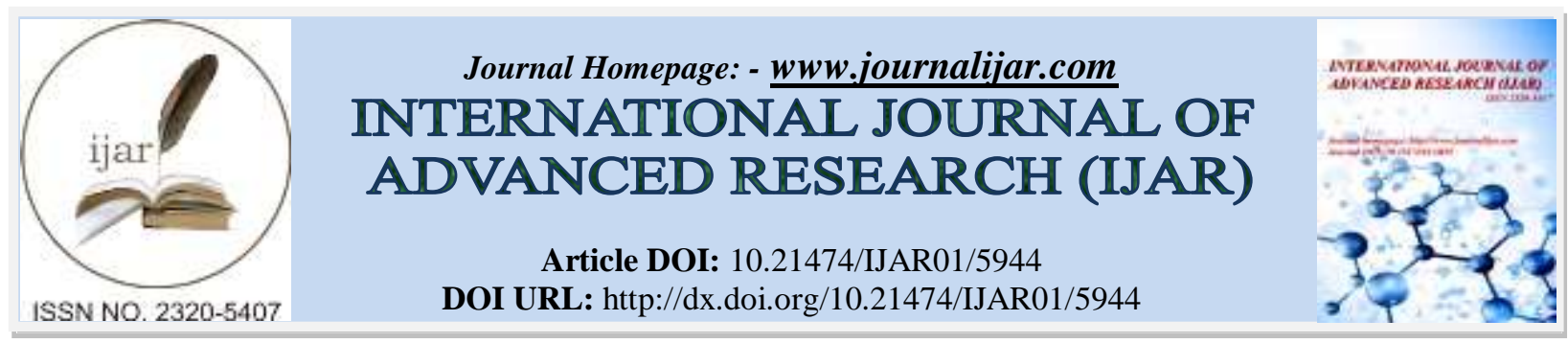

RESEARCH ARTICLE

\title{
CHANGES IN DAILY TEMPERATURE EXTREMES OVER BENIN BETWEEN 1970 AND 2015.
}

\section{Houngninou B. Etienne ${ }^{1}$, Allé C. S. Ulrich ${ }^{2}$, Kougbéagbédè Hilaire ${ }^{1}$ and Guédjé K. François $^{1}$.}

1. Département de Physique, Faculté des Sciences et Techniques, Université d'Abomey-Calavi.

2. Chaire Internationale en Physique Mathématique et Applications (CIPMA - Chaire UNESCO), Faculté des Sciences et Techniques, Université d'Abomey-Calavi.

\section{Manuscript Info}

Manuscript History

Received: 02 October 2017

Final Accepted: 04 November 2017

Published: December 2017

Key words:-

climate extreme indices, temperature, climate change, West Africa, Benin.

\begin{abstract}
Four indices were used to assess changes in both cold and hot tails of the daily temperature distributions. The analysis is based on long-term daily maximum and minimum temperature spanning the period from 1970 to 2015 . The linear trend in the derived temperature indices was computed using the ordinary least squares (OLS) method. The significance of the trend was assessed using the Mann-Kendall test. Results showed significant changes in temperature extremes corresponding to a warming, especially for cold nights and warm nights. The results indicate a significant decrease in the frequency of cold nights (trend $=-14.2$ days/decade) and a significant increase in the occurrence of warm nights (14.6 days/decade). Daily maximum temperature indices showed similar changes but with smaller magnitudes.
\end{abstract}

Copy Right, IJAR, 2017,. All rights reserved.

\section{Introduction:-}

Extremes daily maximum and minimum temperatures have warmed for most regions of the world since 1950 (Brown et al., 2008). These events can influence the health and socio-economic activities of humans (Ciais et al., 2005; Garcia-Herrera et al., 2005). Accordingly, the characterization of climate extremes can provide invaluable information for impact assessment studies (El Kenawy et al., 2011). The joint World Meteorological Organization Commission for Climatology (CCl)/World Climate Research Program (WCRP) project on Climate Variability and Predictability (CLIVAR) Expert Team on Climate Change Detection, Monitoring and Indices (ETCCDMI) defined 27 climate extreme indices (Karl et al., 1999) derived from daily temperature and precipitation data, with a primary focus on extreme events. A website, http://ccma/seos.uvic.ca/ETCCDMI, dedicated to this effort provides comprehensive descriptions of all of the indices, details of quality control procedures and references to relevant literature (Alexander et al., 2006). Recently, several studies have analyzed temperature extremes at different spatial scales, ranging from the regional to the global (Peterson, 2005; Vincent et al., 2005; Zhang et al., 2005a; Aguilar et al., 2005; New et al., 2006; Alexander et al., 2006). In general, most of the findings revealed a significant upward (downward) trend in the duration and frequency of hot (cold) extremes (El Kenawy et al., 2011). Nonetheless, the characteristics of temperature extremes are still incompletely understood at smaller scales, especially in West Africa. The objective of this paper is to analyze trends in daily maximum and minimum temperature over Benin in using 4 extreme temperature indices defined by ETCCDMI.

Corresponding Author:- Houngninou B. Etienne.

Address:- Département de Physique, Faculté des Sciences et Techniques, Université d'Abomey- 


\section{Data and methods:-}

Study area:-

The study area is Benin (Fig. 1). It is located in the geographical coordinates an $\mathbf{N}^{\prime} \mathbf{3 0} \mathbf{9}^{\circ} \mathbf{9 d} \mathbf{E}$ in tropical ${ }^{\prime} \mathbf{1 5}^{\circ} \mathbf{2}$ region in West Africa. Its area is $114.763 \mathrm{~km}^{2}$. The climate is generally of tropical type, and the annual mean temperature varies between 24 and $31{ }^{\circ} \mathrm{C}$ in the South and between 20 and $35{ }^{\circ} \mathrm{C}$ in the far North.

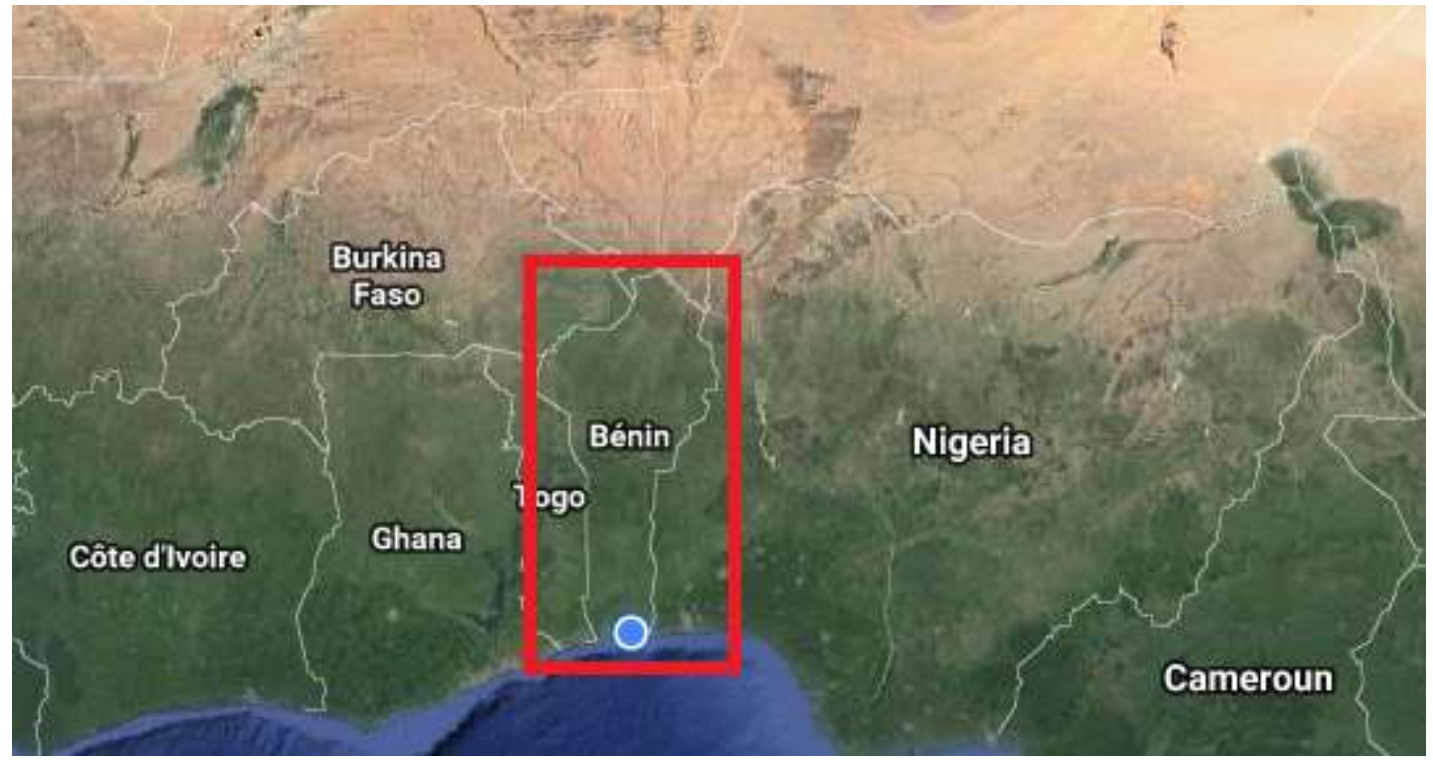

Fig. 1:- Location of Benin in West Africa

\section{Data used:-}

The data used in this study are the daily maximum and minimum temperature time series from the 06 synoptic stations of Benin (Fig. 2). The dataset span the period 1970-2015 and was provided by the national meteorological services. All these datasets have been quality controlled. For each station, RClimDex was used in tandem with a software package called RHtest (Alexander et al., 2006) to identify erroneous outliers and artificial step changes caused by changes in the station location, observing procedures and practice, instrumentation changes, etc. (Aguilar et al., 2003).

\section{Definition of extreme indices:-}

Four extreme indices based on daily temperature defined by the ETCCDMI were used in this study to analyze changes in temperature extremes. Details of these indices are shown in table 1. They represent events that occur several times per season or year, giving them more robust statistical properties than measures of extremes which are far enough into the tails of the distribution so as not to be observed during some years (Alexander et al., 2006). These indices are computed with RClimDex for the base period 1981-2010. The bootstrapping procedure proposed by Zhang et al. (2005b) was taken into account. This procedure removes the inhomogeneities and thus eliminates the possible bias in the trend estimation of the relevant indices (Alexander et al., 2006). 


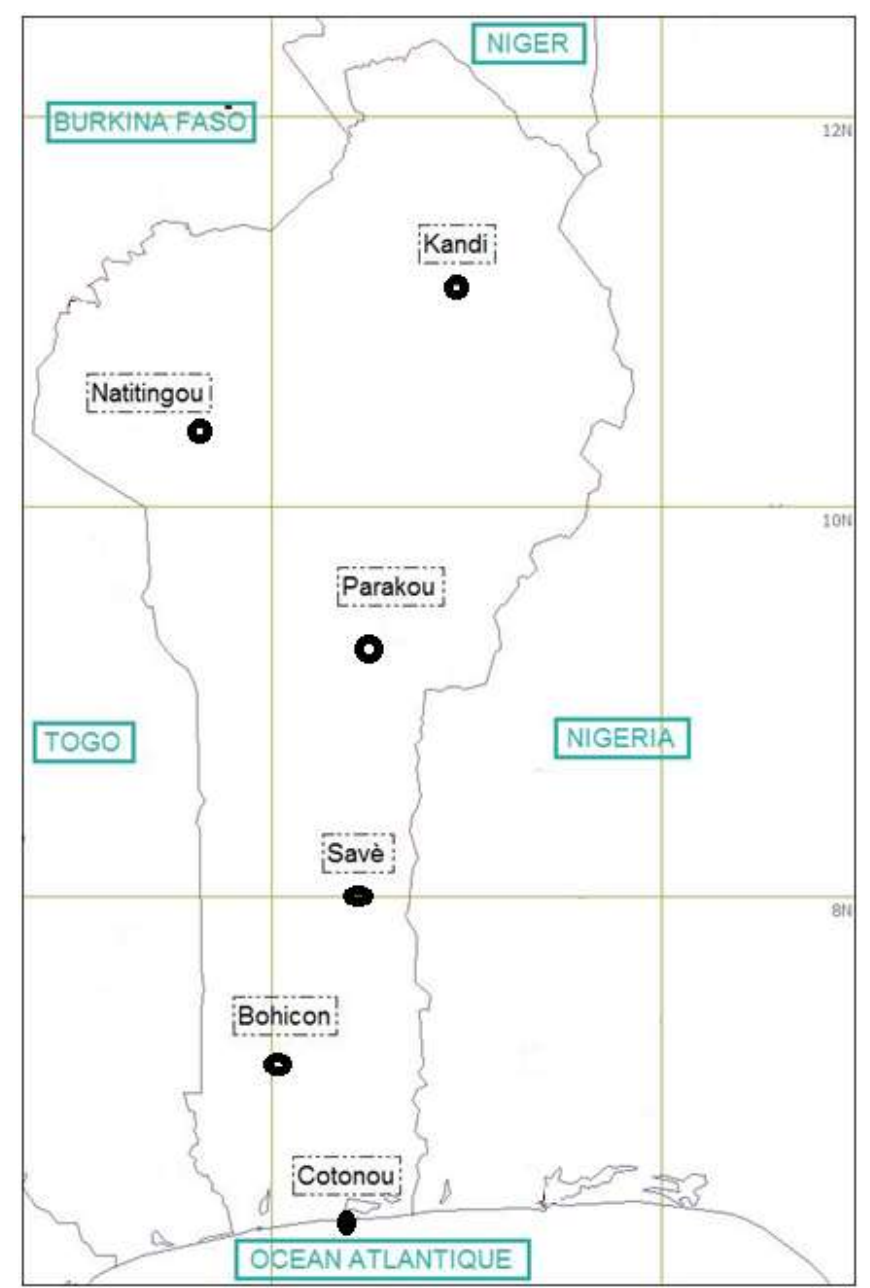

Fig. 2:- Location of the 06 synoptic stations of Benin: Cotonou $\left(06^{\circ} 21^{\prime} \mathrm{N}, 02^{\circ} 23^{\prime} \mathrm{E}, 6,43 \mathrm{~m}\right)$, Bohicon $\left(07^{\circ} 10^{\prime} \mathrm{N}\right.$, $\left.02^{\circ} 04^{\prime} \mathrm{E}, 166,12 \mathrm{~m}\right)$, Savè $\left(08^{\circ} 02^{\prime} \mathrm{N}, 02^{\circ} 28^{\prime} \mathrm{E}, 198,51 \mathrm{~m}\right)$, Parakou $\left(09^{\circ} 21^{\prime} \mathrm{N}, 02^{\circ} 36^{\prime} \mathrm{E}, 391,96 \mathrm{~m}\right)$, Natitingou $\left(10^{\circ} 19^{\prime} \mathrm{N}\right.$, $\left.01^{\circ} 23^{\prime} \mathrm{E}, 460,00 \mathrm{~m}\right)$ and $\mathrm{Kandi}\left(11^{\circ} 08^{\prime} \mathrm{N}, 02^{\circ} 56^{\prime} \mathrm{E}, 289,75 \mathrm{~m}\right)$.

\section{Trend Analysis:-}

The linear trend in the derived temperature indices was computed using the ordinary least squares (OLS) method (El Kenawy et al., 2011). The significance of the trend was assessed using the Mann-Kendall's tau test at the $95 \%$ significance level ( $\mathrm{p}$-value<0.05). This test is mainly because it is robust to outliers and does not assume an underlying probability distribution of the data series (Moberg et al., 2006).

Table 1:- List of indices used in this study and their definitions

\begin{tabular}{|c|l|l|c|}
\hline $\mathrm{N}^{\circ}$ & \multicolumn{1}{|c|}{ Index } & \multicolumn{1}{|c|}{ Definition } & Unit \\
\hline 1 & $\begin{array}{l}\text { Cold days } \\
\text { (TX10p) }\end{array}$ & $\begin{array}{l}\text { Percentages of days with maximum temperatures lower than the } 10^{\text {th }} \text { percentile for } \\
\text { the base period 1981-2010 }\end{array}$ & $\%$ \\
\hline 2 & $\begin{array}{l}\text { Cold nights } \\
\text { (TN10p) }\end{array}$ & $\begin{array}{l}\text { Percentages of days with minimum temperatures lower than the } 10^{\text {th }} \text { percentile for } \\
\text { the base period 1981-2010 }\end{array}$ & $\%$ \\
\hline 3 & $\begin{array}{l}\text { Warm days } \\
\text { (TX90p) }\end{array}$ & $\begin{array}{l}\text { Percentages of days with maximum temperatures higher than the } 90^{\text {th }} \text { percentile } \\
\text { for the base period 1981-2010. }\end{array}$ & $\%$ \\
\hline 4 & $\begin{array}{l}\text { Warm nights } \\
\text { (TN90p) }\end{array}$ & $\begin{array}{l}\text { Percentages of days with minimum temperatures higher than the } 90^{\text {th }} \text { percentile for } \\
\text { the base period 1981-2010. }\end{array}$ & $\%$ \\
\hline
\end{tabular}




\section{Results and Discussion:-}

Brief overview of the climate warming in Benin:

Fig. 3 shows the evolution between 1970 and 2015 of annual mean minimum and maximum temperatures (averaged over Benin). It appears that the minimum and maximum temperatures have been increasing since 1970. However, minimum temperatures have a trend of $0.30^{\circ} \mathrm{C} / \mathrm{dec}$ ade while maximum temperatures have a trend of $0.19{ }^{\circ} \mathrm{C} / \mathrm{dec}$ ade. The minimum temperatures, therefore, increase 1.6 times more than the maximum temperatures. Global warming would, therefore, affect the minimum temperatures more than the maximum temperatures in Benin. However, this result must be relativized. According to Guédjé et al. (2016), the increase in average temperatures in Cotonou (Republic of Benin) since 1987 is mainly conditioned by the increase in maximum temperatures. The trends observed in Benin are relatively higher than those in Africa $\left(0.15^{\circ} \mathrm{C} /\right.$ decade, Collins, 2011$)$.

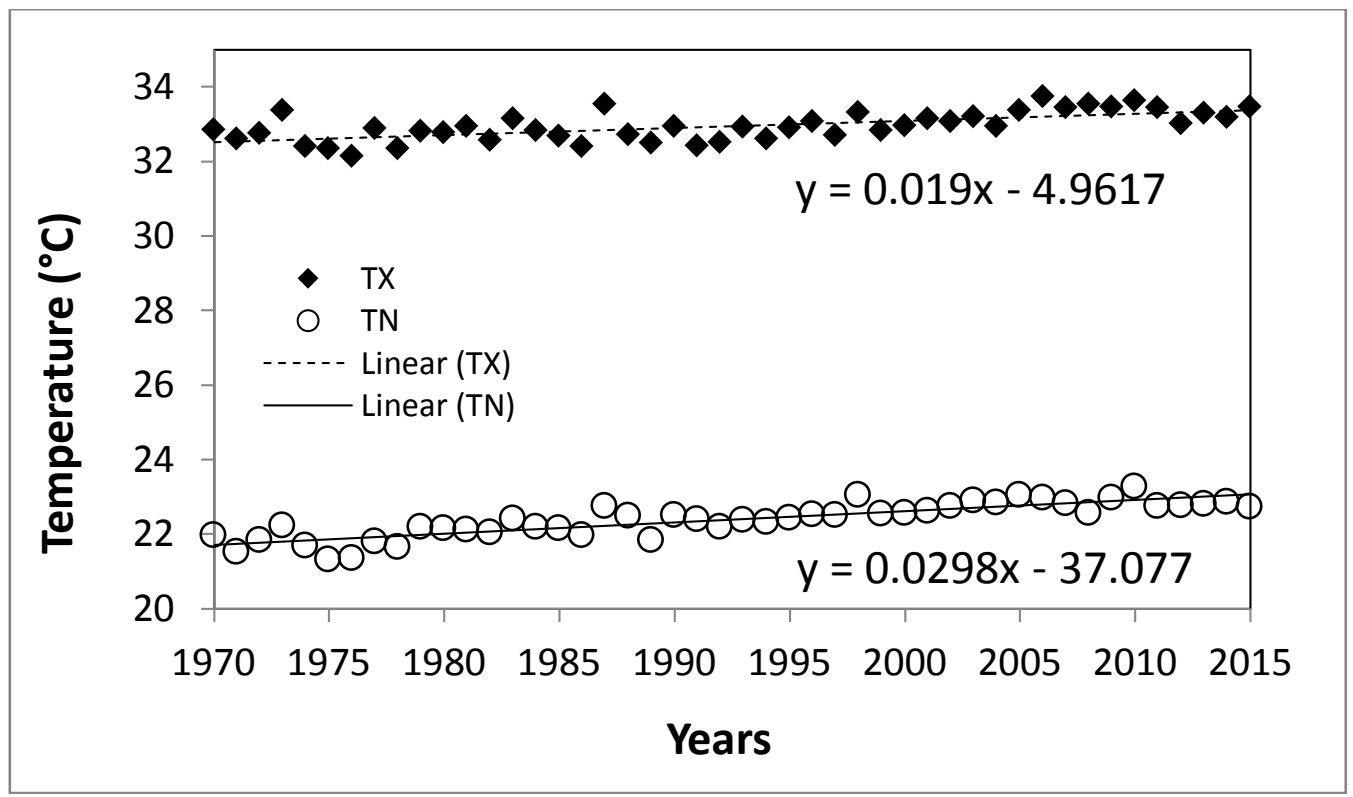

Fig. 3:- Evolution (1970-2015) of maximum (TX) and minimum (TN) temperatures over Benin

\section{Percentile-Based Temperature Indices:-}

Fig. 4 shows the interannual distribution (1970-2015) of cold nights (TN10p), cold days (TX10p), warm nights (TN90p) and warm days (TX90p) averaged on Benin. The trends of these indices are consistent with a warming climate. This warming is characterized by a decrease in cold nights (trend $=-14.2$ days/decade) and cold days (trend $=-6.5$ days/decade) and an increase of the warm nights (trend $=14.6$ days/decade) and warm days (trend $=7.6$ days/decade). These trends averaged in Benin are statistically significant (p-value $<0.05)$ and are in agreement with the global trend (Alexander et al., 2006). The magnitude of the trends is also generally greater for minimum temperature-related extremes (cold nights and warm nights). This finding is consistent with the trends in minimum and maximum temperatures highlighted above (Fig. 3). This constant is also in agreement with the results of previous studies on a global scale (Alexander et al., 2006).

Fig. 5 shows the decadal trends of the percentile-based temperature indices (TN10p, TX10p, TN90p, TX90p) between 1970 and 2015 for each station under observation. The analysis of this figure shows a strong spatial variability of the amplitude of the trends. The upward trend of warm days is not significant (p-value>0.05) at Cotonou and Bohicon stations. Similarly, the downward trend of cold nights is also not significant (p-value $>0.05)$ at Natitingou station. This shows that the magnitude of the percentile-based temperature index trends varies from one region to another in Benin. This spatial variability in temperature trends has also been highlighted by several studies both in Benin (Gnanglè et al., 2011) and elsewhere (Alexander et al., 2006, El Kenawy et al., 2011). 
TN10p

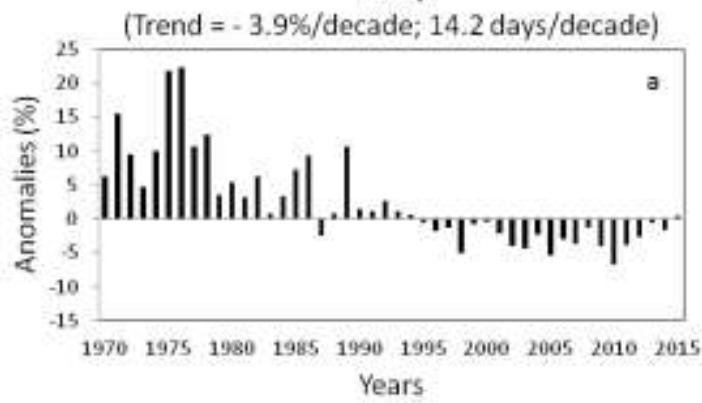

TX10p

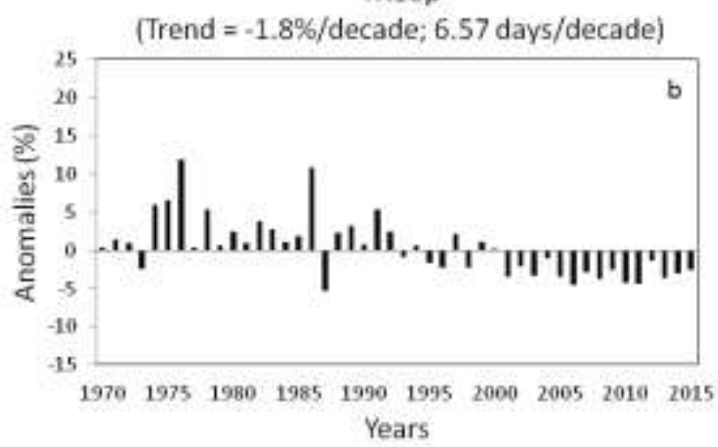

TN90p

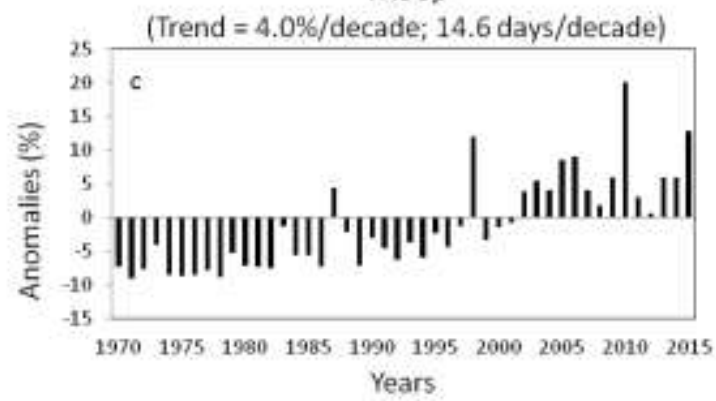

TX90p

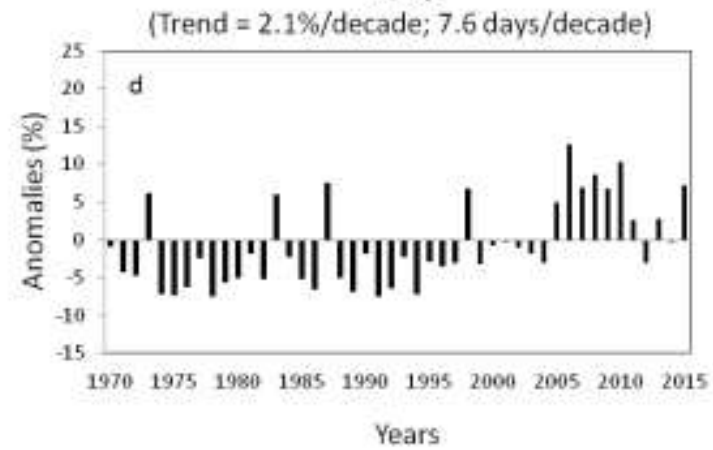

Fig. 4:- Annual time series anomalies relative to 1981-2010 mean values for annual series of percentile temperature indices for 1970-2015 for (a) cold nights (TN10p), (b) cold days (TX10p), (c) warm nights (TN90p) and (d) warm days (TX90p) averaged over Benin.

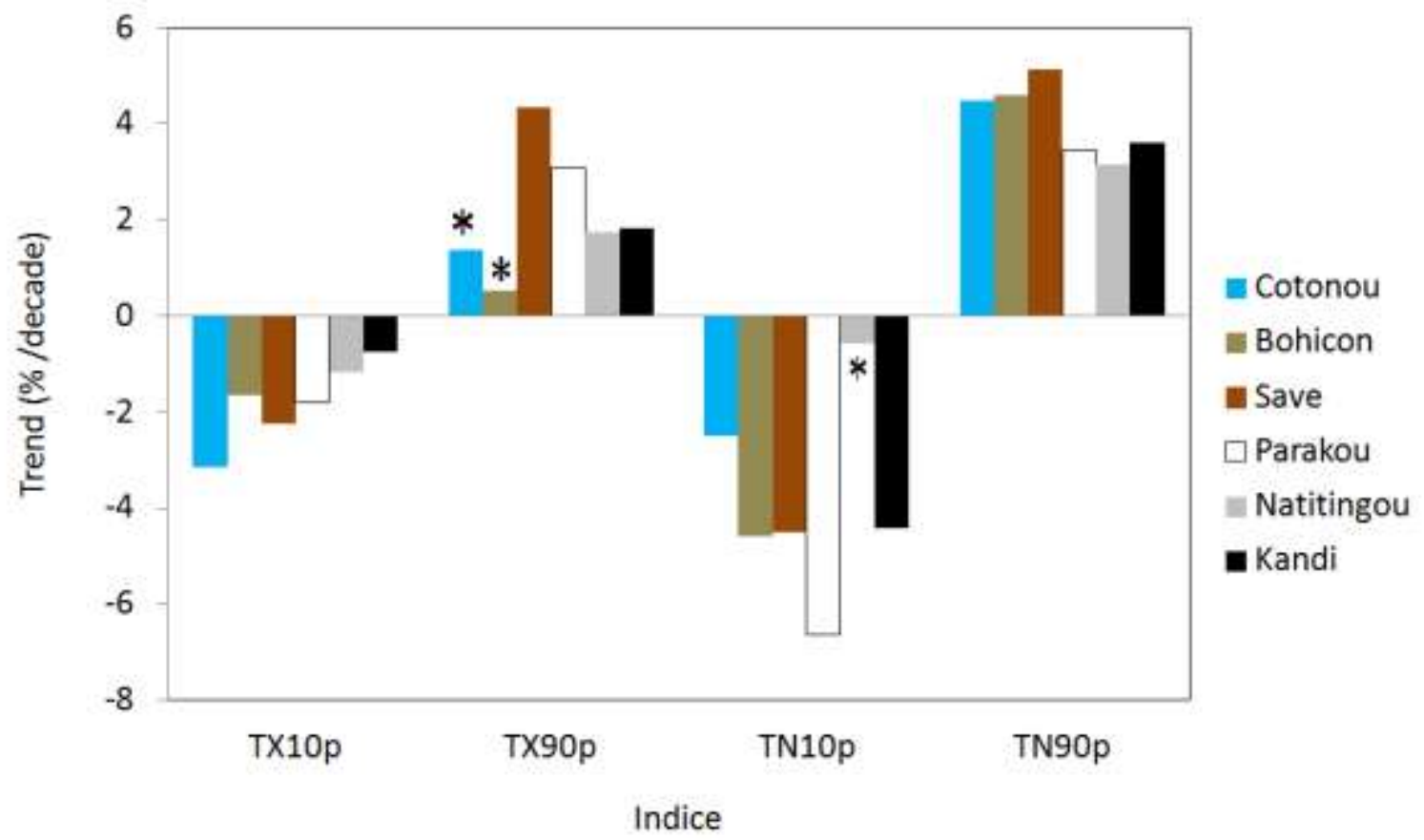

Fig. 5:- Decadal trends of the percentile-based temperature indices (TN10p, TX10p, TN90p, TX90p) between 1970 and 2015 for each station under observation. $\left(^{*}=\right.$ non-significant trend, $\mathrm{p}$-value $\left.>0.05\right)$ 


\section{References:-}

1. Aguilar, E., et al. (2005): Changes in precipitation and temperature extremes in Central America and northern South America, 1961- 2003. J. Geophys. Res., 110: D23107, doi: 10.1029/2005JD006119.

2. Aguilar, E., Auer, I., Brunet, M., Peterson, T. C. and Wieringa, J. (2003): Guidelines on Climate Metadata and Homogenization. WCDMP 53, WMO-TD 1186, 55 pp., World Meteorol. Org., Geneva, Switzerland.

3. Alexander, L. V., et al. (2006): Global observed changes in daily climate extremes of temperature and precipitation. J. Geophys. Res., 111: D05109, doi:10.1029/2005JD006290.

4. Brown, S. J., Caesar J. and Ferro, C. A. T. (2008): Global changes in extreme daily temperature since 1950 . J. Geophys. Res. Atmos., 113: D05115, doi:10.1029/2006JD008091.

5. Ciais, Ph., et al., (2005): Europe-wide reduction in primary productivity caused by the heat and drought in 2003. Nature, 437(7058): 529-534.

6. Collins J.M. (2011): Temperature Variability over Africa. Journal of Climate, 24: 3649-3666.

7. El Kenawy, A., Lopez-Moreno, J. I. and Vicente-Serrano, S. M. (2011): Recent trends in daily temperature extremes over northeastern Spain (1960-2006). Nat. Hazards Earth Syst. Sci., 11: 2583-2603, doi:10.5194/nhess-11-2583-2011.

8. Garcia-Herrera, R., Diaz, J., Trigo, R. M. and Hernandez, E. (2005): Extreme summer temperatures in Iberia: health impacts and associated synoptic conditions. Ann. Geophys., 23: 239-251, doi: 10.5194/angeo-23-2392005.

9. Gnanglè, C.P., Glèlè Kakaï R., Assogbadjo A.E., Vodounnon S., Yabi, J.A. and Sokpon, N. (2011). Tendances climatiques passées, modélisation, perceptions et adaptations locales au Bénin. Climatologie 8: 27-40.

10. Guédjé, F.K., Houngninou, B.E., Honvou, F.S. and Kougbéagbédè H. (2016): Trend of temperatures in Cotonou between 1970 and 2008 in the context of climate change. International Journal of Innovation and Scientific Research, 25(1): 241-245.

11. Moberg, A., et al. (2006): Indices for daily temperature and precipitation extremes in Europe analyzed for the period 1901-2000, J. Geophys. Res., 111: D22106, doi:10.1029/2006JD007103.

12. New, M., et al. (2006): Evidence of trends in daily climate extremes over southern and West Africa, J. Geophys. Res., 111: D14102, doi: 10.1029/2005JD006289.

13. Peterson, T. C. (2005): The workshop on enhancing south and central Asian climate monitoring and indices, Pune, India, February 14 - 19, 2005. CLIVAR Exch., 10(6).

14. Vincent, L. A., et al. (2005): Observed trends in indices of daily temperature extremes in South America 19602000. J. Clim., 18: $5011-5023$.

15. Zhang, X., et al. (2005a): Trends in Middle East climate extreme indices from 1950 to 2003. J. Geophys. Res., 110: D22104, doi: 10.1029/2005JD006181.

16. Zhang, X., Hegerl, G., Zwiers, F. and Kenyon, J. (2005b): Avoiding inhomogeneity in percentile-based indices of temperature extremes. J. Clim., 18: 1641- 1651. 